\title{
RADIO-ULNAR PRONATION VS FOREARM EXTENSION: WHICH THE BEST TO REACH THE MAXIMAL BADMINTON RACKET VELOCITY?
}

\author{
M. Phomsoupha1,, mphomsou@uco.fr, ORCID: 0000-0003-3061-4401, \\ J. Jeuvrey ${ }^{3,4}$, jean.jeuvrey@u-psud.fr, ORCID: 0000-0001-9281-5159, \\ G. Laffaye ${ }^{3,4,5}$, guillaume.laffaye@u-psud.fr, ORCID: 0000-0002-7414-1063 \\ ${ }^{1}$ Université Catholique de l'Ouest, Angers, France, \\ ${ }^{2}$ Université Catholique de l'Ouest - Bretagne Sud, Arradon, France, \\ ${ }^{3}$ Université Paris-Sud, Université Paris-Saclay, Orsay Cedex, France, \\ ${ }^{4}$ Universitéd'Orléans, Orléans, France, \\ ${ }^{5}$ South Ural State University, Chelyabinsk, Russian Federation
}

\begin{abstract}
Aim. Forearm extension and radio-ulnar pronation are two common components of the final movement during each badminton smash stroke. By coordinating the forearm to produce both extension and pronation at the same time, racket head velocity can be increased. Thus, this study examined maximal velocity and racket deflection during both movements in regard with skill level. Materials and methods. Twenty-two players (8 experts and 14 novices) participated in this study. Wrist, handle and racket head velocity were recorded using high speed cameras (Vicon V8i at a frequency of $250 \mathrm{~Hz}$ ). Results. The racket head velocity with radio-ulnar pronation was $16 \%$ higher than with forearm extension. This higher velocity resulted from an $8 \%$ higher acceleration and a $70 \%$ higher maximal angular velocity of the end points of the forearm segments during radio-ulnar pronation. In each movement, experts' maximal velocity was higher than that of novices $(p<.001)$. The maximal velocity of the racket for novices was obtained with elbow extension $(20.9 \pm 4.8 \mathrm{~m} / \mathrm{s})$, with a gain of $47 \%$, whereas for experts, it was obtained with radio-ulnar pronation $(33.9 \pm 5.8 \mathrm{~m} / \mathrm{s})$, with a gain of $53 \%$. Conclusion. The difference between the best velocities in both samples is $39 \%$, obtained respectively by radio-ulnar pronation for experts and an elbow extension for novices. Forearm extension and radio-ulnar pronation acceleration on the handle led to an increase in racket head velocity.
\end{abstract}

Keywords: kinematics, performance, equipment, movement.

Introduction. Overhead movements are used to throw projectiles (e.g. balls, javelins) over distance. Such throwing motions of the upper extremity, where the arm is in abduction, have been analysed in different sports such as handball, volleyball, water polo, and baseball [1]. The different overhead techniques used to launch or strike an object are quite similar in their temporal structure and in the kinematics, as shown by a recent study that compared the tennis serve, volleyball pike and handball throw [33]. In the game of badminton, elite players are able to launch the projectile at high velocity. The fastest shot measured was executed by a Malaysian doubles' player Tan Boon Heong with the speed of $493 \mathrm{~km} \cdot \mathrm{h}^{-1}$ (Yonex, 2013).

To understand how such high velocity is possible, several studies have investigated power strokes, i.e. the clear and the smash [22, 23, 29, 30]. Optimal coordination is brought about by transferring a great force from the lower limb $[24,27]$ to the upper limb [2]. To produce the maximum velocity at the shuttlecock, players add velocity through a sequential proximo-distal joint action [29]. This proximo-distal sequence has also been identified during the tennis serve, volley ball spike and handball throws [33]. Specifically, for anover head stroke, players quickly stretch their forearm during the eccentric phase of the movement (lateral rotation of the shoulder and radio-ulnar supination), followed by a rapid concentric action(medial rotation the shoulder and radio-ulnar pronation) [23, 32]. The inverse sequence is performed for the backhand stroke (stretch by pronation and stroke by supination).

Radio-ulnar pronation contributes to $5 \%$ of the final shuttlecock velocity during a badminton smash $[8,31]$. Elites produce a higher projectile velocity than novices during a smash [29]. Biomechanical analysis has revealed that elite players 


\section{Спортивная тренировка}

gain a major proportion of their power by pronating the forearm [7].

Badminton rackets are composed of a rigid handle and a flexible shaft. The proximal-distal sequence contributes by increasing racket velocity to produce a powerful stroke, that allows the maximization of momentum transfer at impact, including racket velocity [17]. Compared with other racket sports, badminton rackets are relatively flexible [18]. The total velocity of the racket is composed of the swing velocity input by the player's arm movement and an elastic component made up of the racket deflection. Consequently, racket stiffness plays an important role in increasing head velocity [22]. Indeed, the latter is subjected to significant dynamic effect [15]. Furthermore, the mechanism of the racket deflection influences the terminal velocity of the racket head and the terminal velocity of the shuttlecock [25].

Aim. The purpose of the current study was to compare the effect of radio-ulnar pronation of the overarm and the extension of the forearm on terminal racket velocity regarding the level of skill involved.

It is expected that: i) maximal velocity will be higher with radio-ulnar pronation because of the longer acceleration path of the racket that occurs with movement, ii) elite players take greater advantage of radio-ulnar pronation rather than extension

Materials and Methods. Twenty-two participants realised in this study. They were separated into two groups: the expert group, which was composed of eight experienced men (age $23 \pm 3$ years; body mass $76.3 \pm 8.3 \mathrm{~kg}$; height $179 \pm 8.3 \mathrm{~mm}$; amount of training undergone $16.1 \pm 4$ years), and the novice group, which was composed of 14 male participants (age $24 \pm$ \pm 3.5 years; body mass $65.1 \pm 11.5 \mathrm{~kg}$; height $170 \pm 9.0 \mathrm{~mm})$. All participants were healthy and in good physical condition and reported no injuries at the time of the study. They were fully informed about the protocol before participating in this study. Informed consent was obtained from all participants prior to testing, in accordance with the approval of the local ethics committee and current ethical standards in sports and exercise research.

The racket used during the test was identical for all participants (Carlton x 90; $86 \mathrm{~g} ; 675 \mathrm{~mm}$ ). Two conditions (radio-ulnar supination and forearm extension) were included during each session. Each condition was repeated 10 times within a counter-balance order (with 1 min rest), after a general warm-up of 15 minutes.

During the extension condition, participants were instructed to fix the shoulder and the elbow in a $90^{\circ}$ flexion angle in the sagittal plane in a standing position (Fig. 1a). They then extended the forearm in the sagittal plane to give the racket head as high a velocity as possible without the need to move the entire body.

During the radio-ulnar pronation condition, participants were instructed to fix the shoulder and the elbow in a $90^{\circ}$ flexion angle in the sagittal plan in a standing position (Fig. 1b). They then rotated the radio-ulnar pronation to give the racket head as high a velocity as possible without the need to move the entire body, as shown in Fig. 1. Shoulder and elbow velocity must be less than $0.5 \mathrm{~m} / \mathrm{s}$ to validate a trial. In total, $97 \%$ of correct results were used for further analysis.

The experimental setup consisted of a ninecamera Vicon V8i motion capture system set at a frequency of $250 \mathrm{~Hz}$ (Vicon Peak, Oxford, UK). For kinematic analysis, six reflective markers of $14 \mathrm{~mm}$ in diameter were affixed to specific anatomical landmarks (Plug-In Gait Marker Set, Vicon Peak) for each participant. The markers were fixed to the dominant side, as follows: (a) angulus acromialis; (b) medial and lateral humeral epicondyles; (c) radial and ulnar styloid processes; and (d) $2^{\text {nd }}$ metacarpal heads, as recommended by the International Society of Biomechanics [34]. Six reflective markers were affixed to the racket (Fig. 2), as proposed by Kwan et al. [14] in their model: (e) racket handle, bottom and top of the handle; (f) racket shaft, top of the shaft; and $(\mathrm{g})$ racket head, left, right and top of the head. To calculate the joint positions, a 3D model (Plug-In Gait Marker Set, Vicon Peak) was used by David et al. [5]. The reflective markers placed on the racket weighed 1.2-2.4 g each, increasing total mass by $12.4 \mathrm{~g}(14 \%)$.

The accuracy of 3D calibration was $0.2 \mathrm{~mm}$. Only the arm of the racket was analysed. The global $\mathrm{x}$-axis was defined in the anteroposterior, the $\mathrm{z}$-axis vertically and the $y$-axis laterally, whereas the xyplane was identical to the court. The orientation of the humerus, radius, ulna and hand segments was determined by the longitudinal z-axis, the mediolateral $y$-axis, and the perpendicular anteroposterior $\mathrm{x}$-axis, as described in detail by $\mathrm{Wu}$ et al. [34]. The joint elbow flexion angle determined the longitudinal axes of the proximal and distal segments. All calculations were performed 


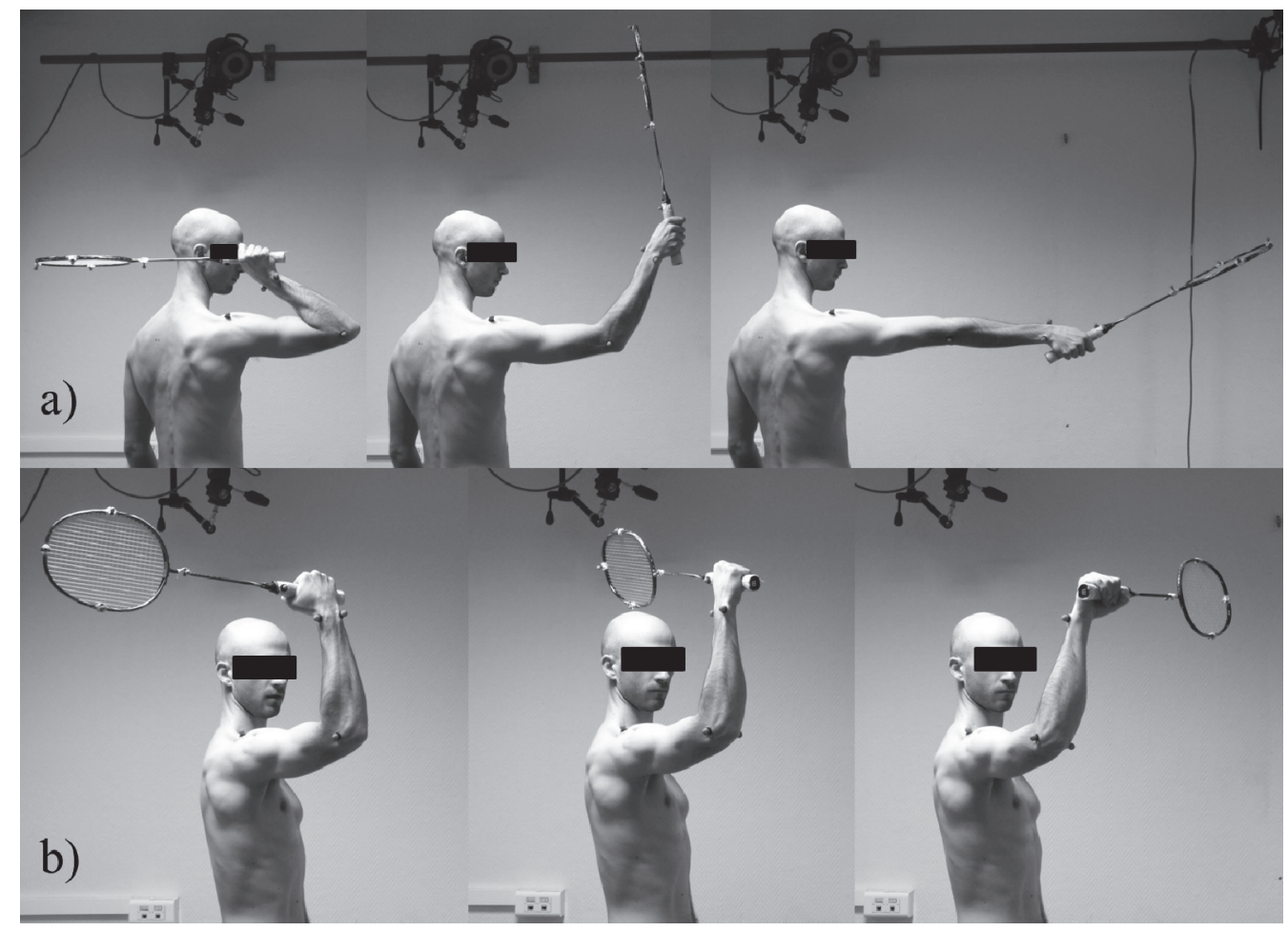

Fig. 1. An example of a forearm stroke with: (a) an elbow extension; and (b) a radio-ulnar pronation

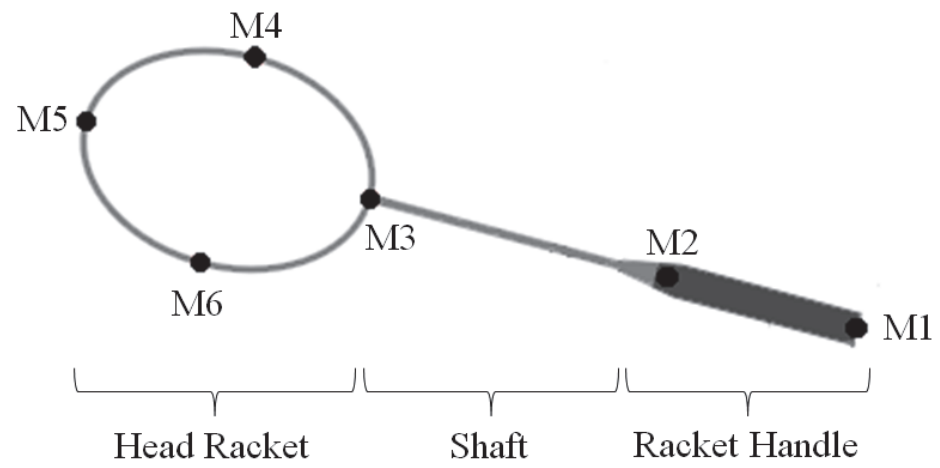

Fig. 2. Illustration of racket anatomy and marker placement for motion capture

using MATLAB R13a software (The Math Works Inc, Natick, MA, USA).

All statistical analyses were performed using Statistica 10 software (StatSoft Inc., Tulsa, OK). Mean and standard deviations of the variables were calculated for descriptive statistics. Groups of variables were used for statistical analysis: (a) maximal velocity in $\mathrm{m} / \mathrm{s}$ (wrist, handle, shaft and head); (b) maximal acceleration in $\mathrm{m} / \mathrm{s}^{2}$ (wrist, handle, shaft and head); (c) maximal angular velocity in $\%$ s (shoulder, elbow and wrist); (d) maximal angle swept in ${ }^{\circ}$ (shoulder, elbow, wrist, handle and head) and (e) maximal angle swept in $\mathrm{mm}$ (racket deflection). To determine the effect of arm movement and skill level we used a two-way repeated measures analysis of variance (ANOVA) with the arm movement (extension vs pronation) as a within subject's factor and the skill level as a between subject's factor. Where the ANOVA was significant, a Fischer post hoc test and power $(1-\beta)$ were performed. For all statistical analyses, significance was set at $p<.05$ and effect size $\left(\eta^{2}\right)$ was defined as small for $\eta^{2}>.01$; medium $\eta^{2}>.09$; and large for $\eta^{2}>.25$ [4].

Results. Experts produced significantly higher maximal velocity than novices, whatever the type of movement $(p<.001)$. In novices, the maximal head velocity was higher with forearm extension than with radio-ulnar pronation $(p<.001)$, whereas it was higher with pronation for experts $(p<.001)$ than for novices. The maxi- 


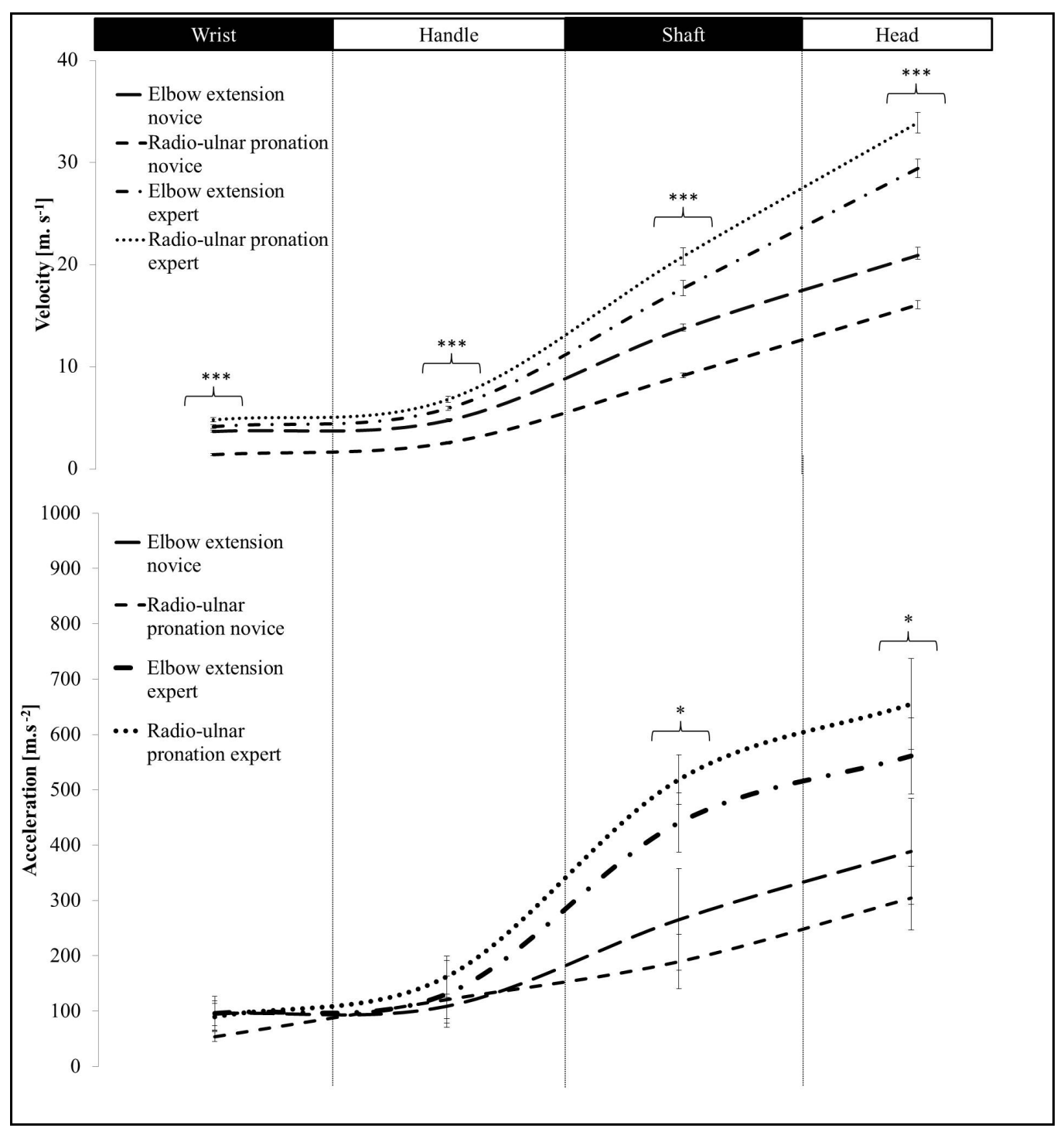

Fig. 3. Maximal linear velocity and acceleration (mean \pm standard error) of the wrist, handle, shaft and head in forearm extension and radio-ulnar pronation and associated significant differences

mal acceleration of the shaft and the head were significantly higher in experts compared with novices $(p<.05)$, whereas there were no significant differences for the wrist and the handle between the two groups (Fig. 3).

The characteristic time for the experts was significantly shorter than that for the novices $(p<.01)$, whereas there was no significant difference in the wrist during radio-ulnar pronation between the two groups. During extension, there were significant differences in the elbow maximal angular velocity (Fig. 4b) between novices and experts $(+39 \%)(p<.05)$. During radio-ulnar pronation, the elbow angular velocity of the experts was significantly larger than that of the novices, as was the experts' extension movement $(+48 \%)(p<.001)$.
There were no significant differences in the swept elbow maximal angle during forearm extension between novices and experts (Fig. 4c). In contrast, during a radio-ulnar pronation, the experts' swept elbow angle was significantly larger than that of the novices, as was the experts' extension movement $(+55 \%)(p<.05)$.

Discussion. The kinematics of two different types of overarm movement (radio-ulnar pronation and elbow extension) in novice and expert badminton players were investigated in this study. The racket head velocity in our study $(33 \mathrm{~m} / \mathrm{s})$ was lower than the values found in earlier research by Kwan et al. [18] where it ranged from 37.5 to $52 \mathrm{~m} / \mathrm{s}$. This could be explained by the movement used in our study, which is part of the global movement performed in other studies. This re- 

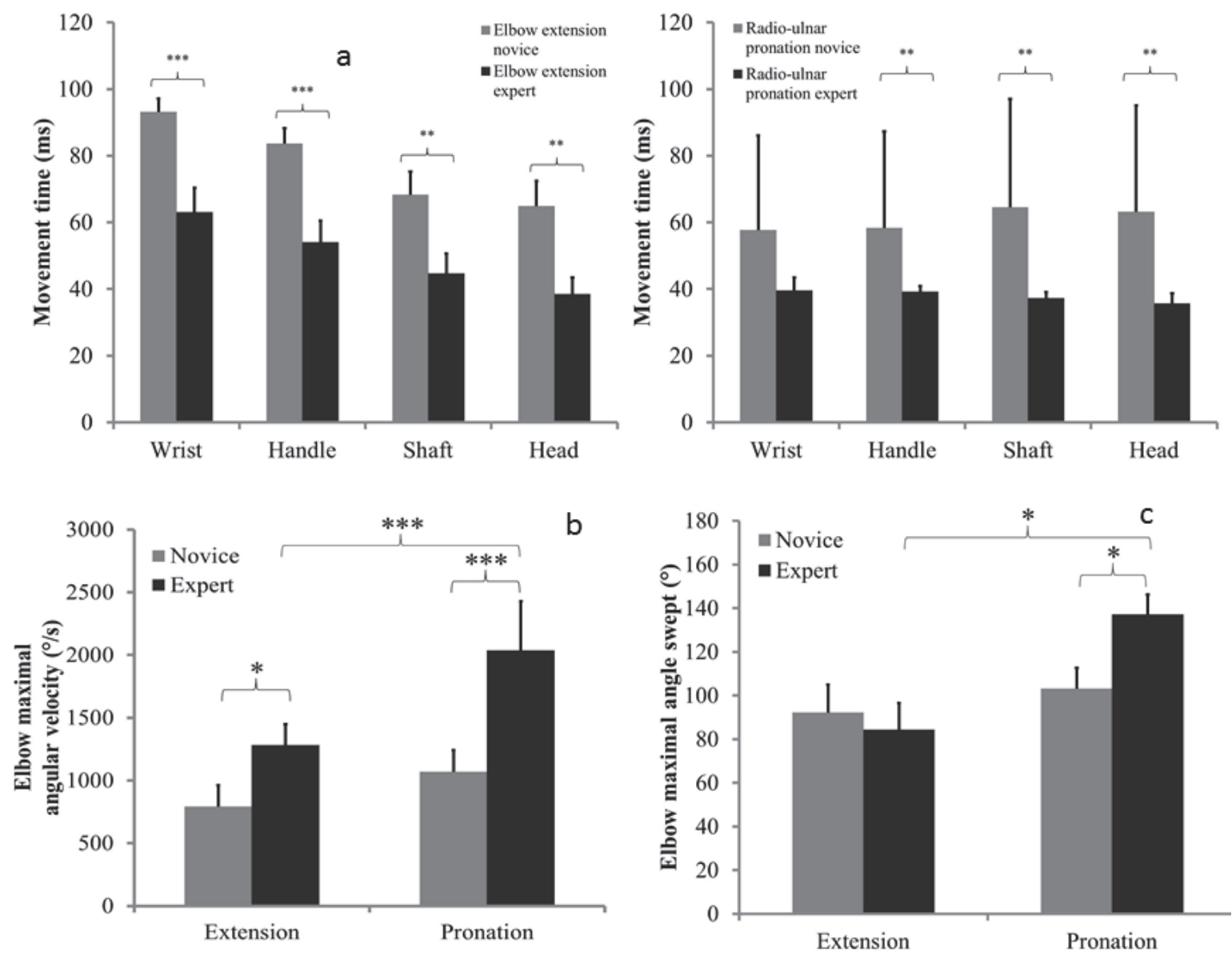

Fig. 4. Characteristic time (a) $(M \pm S D)$ of wrist, handle, shaft and head in forearm extension and radio-ulnar pronation. Maximal angular velocity (b), swept angle (c) of the elbow in forearm extension and radio-ulnar pronation

vealed a contribution of radio-ulnar pronation to the launch velocity of about $57 \%$. The velocity recorded in our study is in line with this value. Indeed, in a study by Gowitzke and Waddell [9] $33 \mathrm{~m} / \mathrm{s}$ represented $53 \%$ of the values. This confirms the work of Tang et al. [28] who reported that the pronation of the forearm was the most important motion during the badminton smash.

The first goal of this study was to compare two kinds of movement in terms of racket terminal velocity. The racket head velocity with radioulnar pronation was $16 \%$ higher than with forearm extension. This higher velocity resulted from an $8 \%$ higher acceleration and a $70 \%$ higher maximal angular velocity of the end points of the forearm segments during radio-ulnar pronation. The elbow angular velocity found in the present study $\left(912.3 \pm 334.3^{\circ} \%\right)$ is close to those found in several studies of extension movement in a badminton jump smash [11, 29] respectively $728.17 \pm 8.77$ and $1035^{\circ}$ s. With radio-ulnar pronation, the angular velocity reaches $2430 \%$, more than $+61 \%$. The angle swept during prona- tion is $25 \%$ higher than with forearm extension, increasing the total time movement and consequently the time to accelerate the racket. These explained why the radio-ulnar pronation produced higher racket velocity.

The second goal of this study was to compare the effect of skill level, with reference to the movement. The maximal velocity of the racket for novices was obtained with elbow extension $(20.9 \pm 4.8 \mathrm{~m} / \mathrm{s})$, with a gain of $47 \%$, whereas for experts, it was obtained with radio-ulnar pronation $(33.9 \pm 5.8 \mathrm{~m} / \mathrm{s})$, with a gain of $53 \%$. The difference between the best velocities in both samples is $39 \%$, obtained respectively by radioulnar pronation for experts and an elbow extension for novices. Thus, radio-ulnar pronation seems to be specifically related to level [21]. Indeed, the literature on the kinematics of badminton has revealed that experts are more efficient when using proximo-to-distal sequence with radio-ulnar pronation [26].

To obtain the maximum velocity, a proximoto-distal sequence [25] (elbow to wrist) was used 


\section{Спортивная тренировка}

to achieve high velocity [19]. However; Marshall and Elliott [20] commented that the traditional concept of proximo-to-distal sequencing is not enough to describe the complexity of racket shots. Indeed, a second mechanism that underpins performance is the stretch-shortening cycle. Increasing supination of the forearm just before its rapid pronation constitutes one such cycle. Thus, when a muscle and tendon complex is first pre-loaded and then stretched immediately afterwards a greater force is generated at the start of the forward movement (up to $150-200 \%$ of isometric force) $[3,13,19]$. Indeed, before beginning the forward movement of the racket head, elite players first use a hyper-supination associated with the internal rotation of the shoulder, followed by a rapid concentric action of pronation without delay. This is contrary to the movement performed by novices [32].

Moreover, this backward hyper-supination allows the expert to increase the swept angle and then the period over which the racket is accelerated. Indeed, according to our study, the angle swept by experts with pronation was greater than that of the novices $(+25 \%)$. In expert players, the gain of the swept angle during radio-ulnar pronation increased the maximal acceleration by $16 \%$ compared with forearm extension.

As mentioned earlier, in this study, maximal velocity of the racket was obtained during forearm extension in novices. This can be explained by the fact that the extension movement of the forearm is a natural motion and people have the ability to master it $[10,12]$. People use their arms to engage in a wide variety of motor tasks preferentially by using an extension of the forearm; for instance by gripping, grasping, or by catching. A badminton stroke has no specific motor pattern; the natural everyday movement mostly influences motor performance [16]. The maximal swept angle is similar for both novices (86.4 \pm $\left.\pm 18.1^{\circ}\right)$ and experts $\left(85.8 \pm 10.1^{\circ}\right)$. This is due to an anatomic limitation during forearm extension, the end stop of the olecranon in the humerus olecranon fossa. Whatever the condition, the movement time of novices is significantly higher than that of experts. This suggests that movement made by novices required more time to reach maximal velocity. Consequently, the maximal angular velocity values obtained whatever the conditions are higher for experts than for novices $\left(1285.6 \pm 167.5^{\circ} / \mathrm{s}\right.$ and $791.3 \pm 171.8 \%$ s during extension; $2036.9 \pm 392.1 \%$ s and $1067.3 \pm 174.5 \% \mathrm{~s}$ during pronation). Experts achieved maximal acceleration earlier than novices $(+31 \%$ extension; $+54 \%$ pronation) during each condition. This suggests that experts are probably able to recruit the motor unit more quickly or achieve a higher firing rate [6]. The higher maximal angle swept during radio-ulnar pronation was comparable with the swept angle during extension for novices and experts $(+10 \%$ and $39 \%$, respectively) needed to increase maximal angular velocity ( $+25 \%$ and $+37 \%$, respectively).

Conclusion. The finding that is of most interest was that forearm rotation movement (radioulnar pronation) increases head racket velocity more than forearm extension movement. It is well known that skill levels have an influence on stroke technique movement. In our study, experts produced higher head velocity regardless of which type of movement was involved. However, novices produced higher maximal velocity on the head racket during forearm extension; conversely, radio-ulnar pronation was higher for experts. Another finding was that racket deflection contributed to an increase in racket head velocity whatever the skill level and movement.

Future studies could include EMG measurements, which can provide extra information for the enhancement of stroke performance. Racket velocity measurement is also necessary to understand the link between the kinematics of the stroke, racket behaviour and projectile velocity.

\section{References}

1. Alfredson H., Pietila T., Lorentzon R. Concentric and Eccentric Shoulder and Elbow Muscle Strength in Female Volleyball Players and Non-Active Females. Scand J Med Sci Sport, 1998, vol. 8, pp. 265-270. DOI: $10.1111 /$ j.16000838.1998.tb00481.x

2. Ariff M., Rambely A.S. Determination of Torques at Upper Limb Joints During Jumping in Badminton Smash via Kane's Method. 26 International Symposium on Biomechanics in Sports, 2008, pp. 73-76.

3. Bosco C., Komi P.V. Potentiation of the Mechanical Behavior of the Human Skeletal Muscle Through Prestretching. Acta Physiol Scand, 1979, vol. 106, pp. 467-472. DOI: 10.1111/j.1748-1716.1979.tb06427.x

4. Cohen J. Statistical Power Analysis for the Behavior Sciences. Lawrence E. Hillsdale; 1988.

5. David R.B., Õunpuu S., Tyburski D., Gage J.R. A Gait Analysis Data Collection and 
Reduction Technique. Hum Mov Sci, 1991, vol. 10, pp. 575-587. DOI: 10.1016/0167-9457(91)90046-Z

6. Duchateau J., Hainaut K. Effects of Immobilization on Contractile Properties, Recruitment and Firing Rates of Human Motor Units. $J$ Physiol, 1990, vol. 422, pp. 55-65. DOI: 10.1113/jphysiol.1990.sp017972

7. Gowitzke B., Waddell D. The Biomechanics of Underarm Power Strokes in Badminton. In: Watkins J., Reilly T., Burwitz L., editors. Sports Science: Proceedings of the VIII Commonwealth and International Conference on Sports, Physical Education, Dance, Recreation and Health, 1985, pp. 137-142.

8. Gowitzke B.A., Waddell D.B. Technique of Badminton Stroke Production: Science in Badminton. Terauds J., Editor. Racquet Sports. Del Mar, CA: Academic Publishers; 1979, pp. 17-41.

9. Gowitzke B.A., Waddell D.B. The Contributions of Biomechanics in Solving Problems in Badminton Stroke Production. International Coaching Conference, 1977.

10. Howard I.S., Ingram J.N., Körding K.P., Wolpert D.M. Statistics of Natural Movements are Reflected in Motor Errors. J Neurophysiol, 2009, vol. 102, pp. 1902-1910. DOI: 10.1152/ jn.00013.2009

11. Hussain I., Paul Y., Bari M.A. Videographical Analysis of Drop and Cut Shot in Badminton. African J Phys Heal Educ Recreat Danc, 2011, vol. 17, pp. 859-864.

12. Joyce G.C., Rack P.M. The Effects of Load and Force on Tremor at the Normal Human Elbow Joint. J Physiol, 1974, vol. 240, pp. 375-396. DOI: 10.1113/jphysiol.1974.sp010615

13. Komi P.V. Elastic Potentiation of Muscles and Its Influence on Sport Performance. Biomech und Sport Leistung, 1983, pp. 59-70.

14. Kwan M., Andersen M.S., de Zee M. et al. Dynamic Model of a Badminton Stroke. Eng Sport. Springer Paris, 2008, vol. 7, pp. 563-571. DOI: 10.1007/978-2-287-09413-2_69

15. Kwan M., Cheng C.L., Tang W.T., Rasmussen J. Measurement of Badminton Racket Deflection during a Stroke. Sport Eng, 2010, vol. 12, pp. 143-153. DOI: 10.1007/s12283-010-0040-5

16. Kwan M., de Zee M., Rasmussen J. Dynamic Effects of Badminton Racket Compliance. $J$ Biomech, 2008, vol. 41, 88 p. DOI: 10.1016/S0021-9290(08)70088-5

17. Kwan M., Rasmussen J. The Importance of Being Elastic: Deflection of a Badminton Racket During a Stroke. J Sports Sci,
2010, vol. 28, pp. 505-511. DOI: 10.1080/ 02640410903567785

18. Kwan M., Skipper Andersen M., Cheng C.L. et al. Investigation of High-Speed Badminton Racket Kinematics by Motion Capture. Sport Eng, 2010, vol. 13, pp. 57-63. DOI: 10.1007/s12283-010-0053-0

19. Lees A. Science and the Major Racket Sports: a Review. J Sports Sci, 2003, vol. 21, pp. 707-732. DOI: 10.1080/0264041031000140275

20. Marshall R.N., Elliott B.C. Long Axis Rotation: the Missing Link in Proximal-toDistal Sequencing. J Sports Sci, 2000, vol. 18, pp. 247-254. DOI: 10.1080/026404100364983

21. Phomsoupha M., Laffaye G. Shuttlecock Velocity During a Smash Stroke in Badminton Evolves Linearly with Skill Level. Comput Methods Biomech Biomed Engin, 2014, vol. 17. DOI: 10.1080/10255842.2014.931550

22. Phomsoupha M., Laffaye G. The Science of Badminton: Game Characteristics, Anthropometry, Physiology, Visual Fitness and Biomechanics. Sport Med, 2015, vol. 45, pp. 473-495. DOI: $10.1007 / \mathrm{s} 40279-014-0287-2$

23. Rambely A.S., Osman N.A.A., Usman J., Wan Abas W.A.B. The Contribution of Upper Limb Joints in the Development of Racket Velocity in the Badminton Smash. 23 International Symposium on Biomechanics in Sports, 2005, pp. 422-426.

24. Rambely A.S., Wan Abas W.A.B. Contact Time and Take-Off Speed Relationship in Determining Height of Jump in Jumping Badminton Smash. 26 International Symposium on Biomechanics in Sports, 2008, pp. 660-663.

25. Rasmussen J., Kwan M., Skipper Andersen M., de Zee M. Analysis of Segment Energy Transfer Using Musculoskeletal Models in a High Speed Badminton Stroke. Proceedings of the 9th International Symposium on Computer Methods in Biomechanics and Biomedical Engineering, 2010, pp. 1-6.

26. Sørensen K. A Biomechanical Analysis of Clear Strokes in Badminton Executed by Youth Players of Different Skill Levels. 2010.

27. Syamimi Kn.Sk., Salim M.S., Omar N. A Biomechanical Analysis of the Knee During Jump Landing. 30th Annual Conference of Biomechanics in Sports, 2012, pp. 265-268.

28. Tang H.P., Abe K., Ae M., Katoh K. Three-Dimensional Cinematographic Analysis of the Badminton Forehand Smash: Movements of the Forearm and Hand. Science and Racket Sports. Cambridge: E. \& F.N. Spon; 1995.

29. Tsai C.L., Chang S.S., Huang C. Bio- 


\title{
Спортивная тренировка
}

mechanical Analysis of Differences in the Badminton Smash and Jump Smash Between Taiwan Elite and Collegiate Players. ISBS'98 - Proceedings II, 2000, pp. 259-262.

30. Tsai C.L., Huang C., Lin D.C. et al. Biomechanical Analysis of the Upper Extremity in Three Different Badminton Overhead Strokes. 18 Int Symp Biomech Sport, 2000, pp. 35-38.

31. Waddell D.B., Gowitzke B.A. Analysis of Overhead Badminton Power Strokes Using High Speed Biplane Cinematography. International Coaching Conference, 1977.

32. Waddell D.B., Gowitzke B.A. Biomechanical Principles Applied to Badminton Power
Stroke. 18 International Symposium on Biomechanics in Sports, 2000, pp. 1-6.

33. Wagner H., Pfusterschmied J., Tilp M. et al. Upper-Body Kinematics in Team-Handball Throw, Tennis Serve, and Volleyball Spike. Scand J Med Sci Sports, 2012, vol. 24, pp. 1-10. DOI: $10.1111 / \mathrm{j} .1600-0838.2012 .01503 . \mathrm{x}$

34. Wu G., van der Helm F.C.T., Veeger H.E.J. et al. ISB Recommendation on Definitions of Joint Coordinate Systems of Various Joints for the Reporting of Human Joint Motion Part II: Shoulder, Elbow, Wrist and Hand. $J$ Biomech, 2005, vol. 38, pp. 981-992. DOI: 10.1016/j.jbiomech.2004.05.042

Received 12 March 2020

\section{ЛУЧЕЛОКТЕВАЯ ПРОНАЦИЯ И РАЗГИБАНИЕ ПРЕДПЛЕЧЬЯ: ЧТО ЛУЧШЕ ДЛЯ ДОСТИЖЕНИЯ МАКСИМАЛЬНОЙ СКОРОСТИ РАКЕТКИ В БАДМИНТОНЕ?}

\author{
м. Фомсуфра ${ }^{1,2}$, Ж. Жевре ${ }^{3,4}$, Г. Лафффайе $e^{3,4,5}$ \\ ${ }^{1}$ Западный католический университет, г. Анже, Франция, \\ ${ }^{2}$ Западный католический университет - Южная Бретань, коммуна Аррадон, Франция, \\ ${ }^{3}$ Университет Париж-Юг, Университет Париж-Сакле, коммуна Орсе, Франция, \\ ${ }^{4}$ Университет Орлеан, г. Орлеан, Франция, \\ ${ }^{5} Ю$ жо-Уральский государственный университет, г. Челябинск, Россия
}

Цель. Разгибание предплечья и пронация лучелоктевого сустава - два стандартных элемента заключительного движения при каждом ударе в бадминтоне. За счет работы предплечья во время разгибания и пронации можно увеличить скорость головки ракетки. Таким образом, цель данного исследования - изучить максимальную скорость и отклонение ракетки при выполнении данных движений в зависимости от уровня игрока. Материалы и методы. В исследовании принимали участие двадцать два игрока (8 профессиональных игроков и 14 новичков). Скорость запястья, рукоятки и головки ракетки регистрировалась с помощью высокоскоростных камер (Vicon V8i с частотой 250 Гц). Результаты. Скорость головки ракетки с лучелоктевой пронацией была на 16 \% выше, чем при разгибании предплечья. Более высокая скорость была вызвана на 8 \% более высоким ускорением и на $70 \%$ более высокой максимальной угловой скоростью конечных точек сегментов предплечья во время лучелоктевой пронации. В каждом движении максимальная скорость профессиональных игроков была выше, чем у новичков ( $<0,001)$. Максимальная скорость ракетки для новичков была получена при разгибании локтя $(20,9 \pm 4,8$ м/c) и продемонстрировала прирост 47 \%. Профессиональные игроки показали максимальную скорость с увеличением на 53 \% во время лучелоктевой пронации $(33,9 \pm 5,8$ м/с). Заключение. Разница между лучшими скоростями в обеих группах составляет 39 \%, полученных, соответственно, во время лучелоктевой пронации у профессиональных игроков и разгибания предплечья у новичков. Под действием разгибания предплечья и лучелоктевой пронации на рукоятку ракетки увеличивается скорость головки ракетки.

Ключевые слова: кинематика, производительность, оборудование, движение. 
Фомсуфа Майкл, доцент, APCoSS - Институт физического воспитания и спортивных наук (IFEPSA), Западный Католический Университет. 49100, г. Анже, Площадь Андрэ Леруа, 3. Франция; Западный католический университет - Южная Бретань. 56610, коммуна Аррадон, Кампюс Вэнсан, Франция. E-mail: mphomsou@uco.fr, ORCID: 0000-0003-3061-4401.

Жевре Жан, Управление научно-исследовательской деятельности, Лаборатория CIAMS, Университет Париж-Юг. 91400, коммуна Орсе, ул. Жоржа Клемансо, 15. Франция; Университет Париж-Сакле. 91400, коммуна Орсе, ул. Жоржа Клемансо, 15. Франция; Лаборатория CIAMS, Университет Орлеана. 45067, Орлеан, пр. Парк Флораль, 6749. Франция. E-mail: jean.jeuvrey@, u-psud.fr, ORCID: 0000-0001-9281-5159.

Лаффайе Гийом, доцент, Лаборатория CIAMS, Университет Париж-Юг. 91400, коммуна Opсе, ул. Жоржа Клемансо, 15. Франция; Университет Париж-Сакле. 91400, коммуна Орсе, ул. Жоржа Клемансо, 15. Франция; Лаборатория CIAMS, Университет Орлеана. 45067, Орлеан, пр. Парк Флораль, 6749. Франция; Южно-Уральский государственный университет. 454080, г. Челябинск, проспект Ленина, 76. E-mail: guillaume.laffaye@u-psud.fr, ORCID: 0000-0002-7414-1063

Поступила в редакцию 12 марта 2020 г.

\section{ОБРАЗЕЦ ЦИТИРОВАНИЯ}

Phomsoupha, M. Radio-Ulnar Pronation vs Forearm Extension: Which the Best to Reach the Maximal Badminton Racket Velocity? / M. Phomsoupha, J. Jeuvrey, G. Laffaye // Человек. Спорт. Медицина. - 2020. - Т. 20, № 2. - C. 99-107. DOI: 10.14529/hsm200212

\section{FOR CITATION}

Phomsoupha M., Jeuvrey J., Laffaye G. Radio-Ulnar Pronation vs Forearm Extension: Which the Best to Reach the Maximal Badminton Racket Velocity? Human. Sport. Medicine, 2020, vol. 20, no. 2, pp. 99-107. DOI: $10.14529 / \mathrm{hsm} 200212$ 